\title{
"BUSYBODIES, CRANKS AND MISCHIEF-MAKERS": REVISITING FINNIGAN V NEW ZEALAND RUGBY FOOTBALL UNION AND THE PRO BONO ETHOS
}

\author{
Jack Alexander*
}

\begin{abstract}
Finnigan v New Zealand Rugby Football Union has assumed a prominent position in New Zealand's relatively short legal history. This is in part due to the legal principles established by the case -it is recognised as a leading case in both administrative law and sports law. The case is perhaps more notable for its social and historical significance - it is fondly remembered as "the case that stopped the tour". This article argues that the case is significant on two further levels. It is a little-known fact that the case was taken on an entirely pro bono basis. The premise of this article is that, without the pro bono ethos of the lawyers involved, one of New Zealand's most famous cases would never have eventuated. The second little-known element of the case is how the plaintiffs' lawyers tactfully avoided the common law doctrine of maintenance. The true significance of Finnigan v New Zealand Rugby Football Union is only realised when the case is examined from a wider perspective than has been done previously.
\end{abstract}

\section{INTRODUCTION}

When assessing New Zealand's leading cases, Justice Glazebrook tellingly included the Finnigan $v$ New Zealand Rugby Football Union (No l $)^{1}$ decisions as part of four pieces of litigation that "have emerged as of true significance in New Zealand's jurisprudence". ${ }^{2}$ The decisions are regularly cited

* LLB (Hons) and BA, University of Auckland. The author would like to thank Dr David V Williams (University of Auckland, Faculty of Law) for his guidance and the Rt Hon Sir Edmund "Ted" Thomas QC for the inspiration behind this article. All errors remain my own.

1 Finnigan v New Zealand Rugby Football Union Inc [1985] 2 NZLR 159 (HC) [Finnigan (No 1) (HC)]; and Finnigan v New Zealand Rugby Football Union Inc [1985] 2 NZLR 159 (CA) [Finnigan (No 1) (CA)].

2 Susan Glazebrook "What Makes a Leading Case? The Narrow Lens of the Law or a Wider Perspective" (2010) 41 VUWLR 339 at 340 . The other cases Glazebrook J chose to discuss were New Zealand Maori 
as leading ones in administrative law ${ }^{3}$ and even sports law. ${ }^{4}$ The legal significance of the decisions is matched only by their historical and social significance. ${ }^{5}$ The subsequent decision to grant an interim injunction in Finnigan $v$ New Zealand Rugby Football Union (No 2$)^{6}$ was "a landmark decision in New Zealand's social history". ${ }^{7}$ In addition to effectively stopping the tour of South Africa, ${ }^{8}$ the Finnigan $v$ New Zealand Rugby Football Union litigation (Finnigan $v N Z R F U$ ) ${ }^{9}$ is credited with "helping to facilitate a broader understanding of race relations in New Zealand". ${ }^{10}$ The late Professor Taggart convincingly argued that the decision "enabled New Zealanders to confront their own past and their own racial stereotyping by forcing them to reflect on how New Zealand had treated its own indigenous people". ${ }^{11}$

Existing scholarship on the case is rather narrow. Taggart has canvased the impact of Finnigan $v$ $N Z R F U$, and other cases arising out of the apartheid regime, on administrative law around the Commonwealth. ${ }^{12}$ Others, such as Simon Watt, have focused on whether the dispute was justiciable given the political background to the case. ${ }^{13}$ This article seeks to add to existing scholarship by focusing on two less well-known aspects of the litigation. The first is the fact that both Finnigan (No 1) and Finnigan (No 2) were taken on a pro bono basis. This was noted by Taggart in passing. ${ }^{14}$ This

Council v Attorney-General [1987] 1 NZLR 641 (CA); Invercargill City Council v Hamlin [1994] 3 NZLR 513 (CA); and Hosking v Runting [2003] 3 NZLR 285 (CA).

3 Professor Taggart noted how the significance of Finnigan (No 1) lies in "its considerable blurring of the line between private law and public law". Michael Taggart "The Impact of Apartheid on Commonwealth Administrative Law" [2006] AJ 158 at 191.

4 As recently as 2013, Finnigan (No 1) was included as one of the 25 most influential cases in international sports law. Jack Anderson Leading Cases in Sports Law (Asser Press, New York, 2013).

5 Glazebrook, above n 2, at 347.

6 Finnigan v New Zealand Rugby Football Union Inc (No 2) [1985] 2 NZLR 181 (HC) [Finnigan (No 2)].

7 Glazebrook, above $\mathrm{n} 2$, at 352.

8 A renegade team (the Cavaliers) would tour South Africa a year later. The Finnigan $v$ NZRFU litigation did however signal the end of New Zealand Rugby Football Union-backed tours.

9 The decisions collectively referred to as the Finnigan $v$ NZRFU litigation are: Finnigan (No 1) (HC), above n 1; Finnigan (No 1) (CA), above n 1; Finnigan (No 2), above n 6; and Finnigan v New Zealand Rugby Football Union Inc (No 3) [1985] 2 NZLR 190 (CA) [Finnigan (No 3)].

10 Glazebrook, above $\mathrm{n} 2$, at 352.

11 At 352

12 Taggart, above n 3.

13 Simon L Watt "Finnigan v NZRFU: Judicial handling of political controversy" (1991) 21 VUWLR 147.

14 Michael Taggart "Rugby, the Anti-apartheid Movement, and Administrative Law" in Rick Bigwood (ed) Public Interest Litigation: New Zealand Experience in International Perspective (LexisNexis, Wellington, 2006) 69 at 92. 
article seeks to further this analysis by examining the pro bono aspects of the litigation in more detail, with particular reference to previous pro bono efforts. The second less well-known aspect is closely related to the first, and deals with how counsel circumvented the common law doctrine of maintenance (which is supposed to prohibit a disinterested third party from encouraging litigation). This was the cause of minor controversy at the time, but subsequent analysis of the litigation either fails to deal with it, or fails to offer an explanation for the lawyers' actions. As Cooke P would go on to observe, the plaintiffs in the case were not simply "busybodies, cranks and mischief-makers". ${ }^{15}$ The story of Finnigan $v$ NZRFU contains useful parables about the lawyer's role in public interest litigation and the importance of taking cases pro bono publico.

This article first considers the "warm up" to the proceedings: the apartheid regime in South Africa, and previous attempts by New Zealand lawyers to stop rugby tours in 1970 and 1981 respectively. Unlike Taggart's work, the focus is less on the legal significance of the cases, and more on their pro bono underpinnings. The article then considers, in Part III, the Finnigan v NZRFU litigation and, more importantly, the questions that arise out of it. This is followed, in Part IV, by an analysis of the doctrine of maintenance and how the lawyers managed to avoid it. Part V discusses the pro bono elements of the litigation in further detail. The article concludes, in Part VI, with a re-evaluation of the significance of the cases in light of these two lesser-known elements. The conclusion reached is that the litigation deserves to be remembered not only for its legal and social significance, but also for the efforts that went on behind the scenes. Without a strong pro bono ethos, two of New Zealand's most famous cases would never have seen the light of day.

\section{THE WARM UP: EARLIER PRO BONO LITIGATION IN NEW ZEALAND}

This section of the article discusses the "warm up" to the Finnigan $v$ NZRFU litigation. It traverses New Zealand's rich, albeit chequered, sporting history with South Africa, and the legal attempts to stop the All Blacks from touring before 1986. Examining these cases reveals a trend of lawyers making themselves available on a pro bono basis to bring legal challenges against All Blacks tours and the apartheid regime in South Africa. More often than not, these challenges were creatively conjured, with lawyers prepared to think outside the box in the fight against apartheid.

\section{A The New Zealand versus South African Sporting Tradition}

South Africa and New Zealand have a strong tradition of sporting rivalry, particularly in the rugby arena. ${ }^{16}$ Professor Taggart went as far as to say that "historically, rugby is what South Africa and New

15 Finnigan (No 1) (CA), above n 1, at 179.

16 The first South African tour of New Zealand was in 1921. The first New Zealand tour of South Africa was in 1928. Richard Thompson Retreat from Apartheid: New Zealand's Sporting Contacts with South Africa (Oxford University Press, New York, 1975) at 14. 
Zealand have most in common". ${ }^{17}$ Nevertheless by the late 1950s, New Zealand's love affair with South African rugby began to sour. Initial opposition to All Blacks tours of South Africa centred on the lack of Māori in touring squads. ${ }^{18}$ This is evident from contemporary pamphlets, which criticise the "all white All Blacks". ${ }^{19}$ This resulted, in 1967, with the New Zealand Rugby Football Union deciding against sending a team to South Africa.

In 1970, it was announced that the All Blacks were to tour South Africa. This time, protests were not grounded on the exclusion of Māori from the touring team; the South African Rugby Board had changed their policy so as to allow "non-whites" in the New Zealand touring team. Rather, protests began to take what Professor Taggart described as "a more overt anti-apartheid focus". ${ }^{20}$ This is evident from contemporary sources. A pamphlet issued by Citizens Association for Racial Equality (CARE) has James K Baxter on record as opposing the tour: ${ }^{21}$

The All Black tour of 1970 ceased to be a sporting event from the time organisations representing black Africans in South Africa communicated their lack of approval. Any man who is not a racist, and who is in favour of the tour, needs his head read. The issue does not turn on whether or not the South African Government treats Māori well. It turns on support for black Africans.

Ex-All Black Bill Meates was similarly opposed: ${ }^{22}$

As a sportsman, as a Christian, and as a New Zealander, I oppose the proposed 1970 All Black tour of South Africa. I cannot condone the system of apartheid, which takes away such an elementary human right as the right to meet on equal terms on the field of sport.

\section{B Pro Bono's First Appearance: Parsons v Burk}

The announcement of the prospective tour of South Africa in 1970 also divided opinion within New Zealand's legal community. The Chief Justice, Sir Richard Wild, was quoted as saying the All Blacks "must go; they will go".23

Against the wishes of the Chief Justice, Roy Parsons (a modest bookseller in Wellington) and Dr George Barton (of the Victoria University of Wellington Faculty of Law, and a figure who will

17 Taggart, above n 3, at 158 .

181960 is the crucial date in this respect. Thompson, above n 16, at 5.

19 At 5 .

20 Taggart, above n 3, at 158.

21 Citizens Association for Racial Equality I'm Against the Tour (Citizens Association for Racial Equality, Auckland, 1970) at 10.

22 At 9 .

23 Taggart, above n 3, at 159. 
reappear later in the story) issued the first legal challenge to a New Zealand rugby tour of South Africa.

In an attempt to stop the All Blacks leaving New Zealand, the applicant in Parsons $v$ Burk sought to invoke the historic writ ne exeat regno. ${ }^{24}$ As Professor Taggart explained, the writ was: ${ }^{25}$

... historically the means by which the Monarch could prevent subjects leaving the realm either to ensure

their availability to assist the Crown in times of emergency or to prevent them causing trouble or mischief

overseas.

Parsons, with the support of Dr Barton, creatively argued that the writ was available at the invocation of a private individual. The tenuous support for this proposition came from the 1534 treatise Fitzherbert's New Natura Brevium. ${ }^{26}$ Hardie Boys J nevertheless held that "only the Crown ... [had] standing to seek the writ for political purposes". ${ }^{27}$ Fitzherbert's New Natura Brevium was not "clear authority or precedent" to the contrary. ${ }^{28}$ The tour would go ahead.

For the purposes of this article, the significance of Parsons $v$ Burk does not lie in the administrative law point Professor Taggart draws our attention to. Rather, the case is notable as the first - and certainly not the last - creative attempt by a team of lawyers to prevent the All Blacks from touring South Africa. And, as with the cases that were to follow, this case was only made possible by a lawyer (Dr Barton) appearing as counsel pro bono publico. ${ }^{29}$

\section{The Period Between 1970 and 1980}

Trevor Richards notes how the difference between the case of Parsons $v$ Burk "and that of Finnigan and Recordon lies not so much in the law relevant to the two cases as in an examination of the events of the intervening years" - "the injunction which sunk the 1985 tour of South Africa would not have been issued without the events of 1981 and 1976". ${ }^{30}$ Examining this period is therefore a crucial precursor to analysing the Finnigan $v$ NZRFU litigation.

24 Parsons v Burk [1971] NZLR 244 (SC).

25 Taggart, above n 3, at 160 .

26 Anthony Fitzherbert La Novelle Natura Brevium (London, 1954). The writ was also discussed in Flack $v$ Holm (1820) $1 \mathrm{~J} \& \mathrm{~W} 406$ (Ch).

27 Taggart, above n 3, at 160 .

28 Parson v Burk, above n 24, at 248.

29 The instructing solicitor was Keith Matthews of Tripe, Matthews and Feist. Victoria University of Wellington "A Year in Review 2014" (November 2014) <www.victoria.ac.nz>.

30 Trevor Richards Dancing On Our Bones: New Zealand, South Africa, Rugby and Racism (Bridget Williams Books, Wellington, 1999) at 234. 
When Parsons' legal challenge failed, the 1970 tour went ahead. The years that followed were characterised by increasing concern amongst New Zealanders. In 1972 a "conference to consider New Zealand's relations with racism and colonialism in South Africa" garnered widespread support. ${ }^{31}$ This was followed by the widespread publication of Fight Apartheid: A Manual for Action - "the first major attempt by any group ... to bring together information and source material on racism and colonialism in Southern Africa which can be a guide to practical activity". ${ }^{32}$ The Manual for Action provides useful information about other anti-apartheid groups that were active in this period, such as Halt All Racist Tours (HART) and CARE. The former "opposed nine sports tours involving racist South African teams during 1971 and 1972". 33 These were not limited to the rugby arena, with HART opposing cricket tours, surf lifesaving tours and everything in between. ${ }^{34}$ Increasing public pressure in New Zealand, combined with the fear of other African nations boycotting the Commonwealth Games that were to be held in Christchurch the following year, resulted in the Labour Government calling off the 1973 tour. ${ }^{35}$

However, the election of the National Party in 1975 precipitated a shift in policy, and in 1976, the All Blacks toured South Africa. ${ }^{36}$ The 1976 tour was as controversial as those that preceded it, with a number of African nations boycotting the Montreal Olympic Games as a result of the International Olympic Committee's decision not to ban New Zealand from competing. By 1977, the tides had seemingly turned again. A proposed New Zealand Māori tour of South Africa was cancelled, and the Commonwealth Heads of Government also entered into the Gleneagles Agreement to abstain from sporting contact with South Africa. ${ }^{37}$ Richards concludes his analysis of this period by describing it as a "rollercoaster ride of dramatic scale and scope", although this would ultimately pale in comparison to the events of 1981 and $1985 .{ }^{38}$

\section{The Events of 1981}

In 1980, the New Zealand Rugby Union invited the Springboks to visit in 1981. The tour ultimately went ahead, but "was bitterly opposed by a significant minority of New Zealanders" and,

31 Christopher Wainwright and Lindsay Wright Fight Apartheid: A Manual for Action (National Anti-Apartheid Coordinating Committee, Wellington, 1972).

32 At 1.

33 At 11.

34 At 11.

35 Taggart, above n 3, at 164.

36 At 164 .

37 The Gleneagles Agreement: Commonwealth Statement on Apartheid in Sport (signed 14 June 1977).

38 Richards, above n 30, at 134. 
as will be examined in this section, gave rise to a number of different lawsuits. ${ }^{39}$ These ranged from highbrow administrative law cases to civil disobedience ones. However, constant throughout was the willingness of lawyers to assist plaintiffs (and in the latter string of cases, defendants) pro bono publico.

\section{Pro bono's second appearance: Ashby v Minister of Immigration}

The most well-known case arising prior to the 1981 tour was Ashby v Minister of Immigration. ${ }^{40}$ The applicants sought to challenge the Minister of Immigration's decision to grant visas to the South African team. The challenge was couched in terms of the Wednesbury unreasonableness test, as well as the direct applicability of the International Convention of the Elimination of All Forms of Racial Discrimination (CERD) to New Zealand's domestic law. ${ }^{41}$ This argument failed in the High Court ${ }^{42}$ and the Court of Appeal. ${ }^{43}$ The Ashby litigation is interesting for a number of reasons. Counsel for the applicant was Dr Barton, who appeared pro bono publico. ${ }^{44}$ The case is therefore a continuance of the pro bono theme that first became apparent in Parsons $v$ Burk. The case is also interesting in so far as it reveals a trend of certain individuals being prepared to assist in the fight against apartheid. One will recall that Dr Barton was counsel 10 years earlier in Parsons v Burk. The willingness of certain lawyers to take anti-apartheid cases is a theme that will be picked up later.

\section{Clements v Attorney-General}

A less well-known case from 1981 is the unreported High Court decision in Clements $v$ AttorneyGeneral. ${ }^{45}$ Dr Clements requested that the Attorney-General refuse the Springbok team entry into New Zealand under s 5(1) of the Undesirable Immigrants Exclusion Act 1919, which gave the Attorney-General the discretionary power to refuse entry if "satisfied" that a person's presence "would be injurious to the peace, order, and good government" of New Zealand. The Attorney-General refused to exercise the power, and Dr Clements sought judicial review of that decision. Unfortunately, the decision in Clements $v$ Attorney General is unreported. This leaves a number of questions awaiting further research. The first question is whether Dr Clements was a self-represented litigant, or whether

39 Taggart, above n 3, at 165.

40 Ashby v Minister of Immigration [1981] 1 NZLR 222 (CA).

41 Associated Provincial Picture Houses Ltd v Wednesbury Corp [1948] 1 KB 223; and International Convention on the Elimination of All Forms of Racial Discrimination 660 UNTS 195 (opened for signature on 21 December 1965, entered into force 4 January 1969).

42 Minister of Immigration v Ashby HC Wellington A169/81, 10 July 1981.

43 Ashby v Minister of Immigration [1981] 1 NZLR 222 (CA).

44 Taggart, above n 3, at 160.

45 Clements $v$ Attorney-General HC Christchurch M307/81, 17 July 1981. The author is indebted to the late Professor Taggart for this reference, and his summary of the case. 
he enlisted the assistance of a lawyer as counsel (perhaps pro bono publico). The second question relates to the identity of the second applicant in the case (who is left unnamed, but may well have been a lawyer).

\section{Dr Elkind's application to the New Zealand Humans Rights Commission}

Legal attempts to stop the tour in 1981 were not confined to the courtroom. Dr Jerome Elkind (of the University of Auckland Faculty of Law) also mounted a challenge before the New Zealand Human Rights Commission. Supporters of Dr Elkind's challenge included Professor Jack Northey (then Dean of the University of Auckland Faculty of Law) and Dr Martyn Finlay (former Solicitor-General). Details of the case are not to be found in any law reports, but are recounted in a journal article and a conference paper. ${ }^{46}$

In 1977, Commonwealth Presidents and Prime Ministers had signed the Gleneagles Agreement. This obligated signatories, including New Zealand, to: ${ }^{47}$

Vigorously combat the evil of apartheid by withholding any support for, and by taking every practical step to discourage contact or competition by their nationals with sporting obligations, teams or sportsmen from South Africa or from any other country where sports are organised on the basis of race, colour, or ethnic origin.

Dr Elkind took two issues to the New Zealand Human Rights Commission. The first was whether the Gleneagles Agreement created rights and obligations of a legal nature. ${ }^{48}$ The New Zealand Government denied this. ${ }^{49}$ The second issue was whether the Gleneagles Agreement, if binding, could be interpreted so as to require the Government to stop the 1981 tour. ${ }^{50}$

On the first issue, the Commission held that, whilst the Gleneagles Agreement was "a policy statement of great significance", "in form and expression it [was] clearly a political and not a legal statement". ${ }^{51}$ The finding on the first issue meant that the Commission was not required to come to a binding conclusion on the second issue.

46 Jerome Elkind and Antony Shaw "The Municipal Enforcement of the Prohibition Against Racial Discrimination: A Case Study on New Zealand and the 1981 Springbok Tour" (1984) 55 BYBIL 189; and Jerome Elkind "New Zealand, the Springboks, and International Law" (paper presented to the Australasian Universities Law Schools Association Conference, Hobart, Tasmania, 1982).

47 Gleneagles Agreement, above n 37, para 7.

48 Elkind and Shaw, above n 46, at 192.

49 At 192

50 At 192

51 At 193 
Although unsuccessful, Dr Elkind's application to the Human Rights Commission remains significant in so far as it shows how academic lawyers were also willing to donate their time to the fight against apartheid. This was examined in Parsons $v$ Burk, where it was noted that Dr Barton was a member of the Victoria University Faculty of Law (although by the time of the Ashby litigation he had left academia to pursue a career as a barrister).

\section{The civil disobedience cases and the offer of pro bono representation}

Confrontations between police and protestors in 1981 resulted in some 2,000 arrests; 2,254 charges were laid against a total of 1,520 people. ${ }^{52}$ Although some of these charges were later dropped, the ensuing lawsuits kept the New Zealand courts occupied for the rest of the year. ${ }^{53}$

Many of those charged made a conscious choice to represent themselves in proceedings, rather than seeking a lawyer to appear on their behalf. This was in line with the purpose of the protests - to bring the court system to a standstill. ${ }^{54}$

However, as trials approached, a not insignificant proportion of those arrested sought the aid of lawyers to help with their defence. To this end, Ted Thomas recalls how panels of lawyers were set up in Auckland and Wellington who were prepared to offer pro bono legal assistance to those in need. ${ }^{55}$

The establishment of pro bono panels in 1981 is significant for two reasons. First, it adds to the recurring theme of lawyers offering their services pro bono publico in the fight against apartheid. Secondly, two of the lawyers involved in setting up the panels would play a central part in the proceedings in the 1985 litigation (Rodney Hansen and Patrick Finnigan).

52 Richards, above n 30, at 225. For general reading, refer to Don Cameron Barbed Wire Boks (Rugby Press, Auckland, 1981); Geoff Chapple 1981: The Tour (AH and AW Reed, Wellington, 1984); Tom Newham By Batons and Barbed Wire (Graphic Publications, Wellington, 1981); and Richard Shears and Isobelle Gidley Storm Out of Africa: the 1981 Springbok Tour of New Zealand (Macmillian, Auckland, 1981).

53 Redmer Yska "Inside the 1981 Springbok Tour" New Zealand Listener (online ed, New Zealand, 9 July 2011).

54 The protestors largely succeeded - "the courts were tied up for the rest of the year". Yska, above n 53.

55 Interview with Edmund Thomas (Jack Alexander, Auckland, 18 March 2016). This is consistent with the movement in the late 1970s to "make the justice system more accessible to lay people", with the appearance of Neighbourhood Law Offices. Peter Spiller "The Legal Profession" in Peter Spiller (ed) A New Zealand Legal History (2nd ed, Brookers, Wellington, 2001) 272 at 273. 


\section{THE LITIGATION}

This section of the article outlines the general course of the Finnigan $v$ NZRFU litigation. ${ }^{56}$ It then focuses on the specific questions that arise for consideration. These are the problem of maintenance, and the fact that the case was taken pro bono publico. These will be discussed in turn.

\section{A Overview of Proceedings}

On 17 April 1985, the Council of the New Zealand Rugby Football Union (the Council) accepted the invitation of the South African Rugby Board for a New Zealand representative rugby team to tour South Africa.

On 20 May 1985, Patrick Finnigan of the Auckland University Rugby Football Club and Philip Recordon of the Teachers' Rugby Football Club commenced action in the High Court. The argument in the statement of claim was that the Council's decision did not comply with the objects stated in the Rules of the New Zealand Rugby Football Union. ${ }^{57}$

Eleven days later, on 31 May 1985, the defendants applied to the High Court for a strike out. The foundation for the strike out application was that the plaintiffs did not have standing. This argument succeeded in the High Court. ${ }^{58}$ The plaintiffs appealed, and on 21 June 1985, the Court of Appeal overturned the High Court decision. ${ }^{59}$ A crucial tenet of Cooke J's decision to grant standing was that the plaintiffs were not "busybodies, cranks and mischief-makers". 60

On 8 July 1985 the plaintiffs applied for an interim injunction in the High Court. ${ }^{61}$ The High Court granted an interim injunction on 13 July 1985, preventing the Rugby Union from commencing the tour of South Africa until the plaintiffs' case had been heard. This effectively ended any chance of the tour going ahead, and on 14 July 1985 the Rugby Union decided not to appeal. ${ }^{62}$

\section{B Questions Arising out of the Proceedings}

A number of questions arise from a reconsideration of the proceedings, leaving aside the substantive issues that were considered during the litigation.

56 This section is necessarily brief. For a thorough overview, see case notes from the time: Cecil Albert Blazey "Finnigan v New Zealand Rugby Football Union" (1985) 102 SALJ 711.

57 The Rules set out that the Union was "to control, promote, foster and develop the game of amateur Rugby Union Football throughout New Zealand". Finnigan (No 1) (HC), above n 1, at 149.

58 Finnigan (No 1) (HC), above n 1.

59 Finnigan (No 1) (CA), above n 1.

60 At 179.

61 Finnigan (No 2), above n 6.

62 Glazebrook, above n 2, at 351. 
The first question is what went on behind the scenes between the announcement of the tour (on 17 April 1985) and the commencement of the action in the High Court (on 20 May 1985). Douglas White, on behalf of the defendants, noted how the lawyers in fact approached the plaintiffs with the case. ${ }^{63}$ Patrick Finnigan confirmed this at the 2012 African National Congress (ANC) Conference in Wellington. ${ }^{64}$ This stands in contrast with traditional notions of the lawyer-client relationship, where the client is expected to approach the lawyer - not the other way around. This concept has been slightly eroded over the years, particularly in the realm of public interest litigation, with David Luban arguing that "it should not matter who recruited whom". ${ }^{65}$ Yet the dominant conception of the lawyer-client relationship, especially in the early 1980s, was that it was the client who should approach the lawyer. Writing in 1986, just one year after the Finnigan v NZRFU litigation, Deborah Rhode reiterated the traditional stance: "business should seek the young attorney, rather than the converse". 66

A closer examination of the period between the announcement of the tour and the commencement of the action in the High Court shows that the lawyers involved actually went a step further. At the 2012 ANC Conference in Wellington, Ted Thomas stated that, "when the proceedings were drafted, we [the lawyers involved] had no plaintiff". ${ }^{67}$ The statement of claim was drafted and lay dormant for two weeks, while the lawyers searched for plaintiffs with appropriate standing. The lawyers first approached the North Harbour Rugby Union and the Auckland Rugby Union who, while sympathetic to the cause, were not prepared to put their names on the lawsuit. ${ }^{68}$ The lawyers subsequently approached Finnigan and Recordon, who agreed to be the plaintiffs - although the former's acceptance was contingent on a memorandum from Professor Taggart! The fact that the lawyers who took the case approached the plaintiffs with a near complete statement of claim raises the question of maintenance, which is supposed to prevent a disinterested party from encouraging litigation. While the prohibition on lawyers advertising (in the business sense) was done away with in 1985, ${ }^{69}$ maintenance remained part of New Zealand law. No proceedings in maintenance were ever taken against the lawyers after the case. The question nonetheless warrants revisiting if it absolves the

63 Taggart, above n 14, at 93.

64 Ted Thomas and others "The NZRFU versus Law: the Significance of the Legal Bid to Stop the 1985 All Black Tour of South Africa" (paper presented to African National Congress Conference, Wellington, 2012).

65 David Luban Lawyers and Justice: an Ethical Study (Princeton University Press, Princeton, 1988) at 318.

66 Deborah Rhode "Solicitation" (1986) 36 J Leg Ed 317. The issue sparked widespread debate in the United States during the 1970s and 1980s. "Advertising, Solicitation and the Profession's Duty to Make Legal Counsel Available" (1972) 81 Yale LJ 1181.

67 Thomas and others, above n 64.

68 Thomas and others, above n 64.

69 Spiller, above n 55, at 275. 
lawyers involved of any wrongdoing or it contributes to our understanding of the common law doctrine of maintenance in New Zealand.

The second question is closely related to the first, and deals with the pro bono aspects of the case. As noted above, the case was taken on an entirely pro bono basis. This alone is worthy of discussion. From the case report, one is able to see that EW Thomas QC and RH Hansen appeared respectively as senior counsel and instructing solicitor pro bono publico, but one suspects that there must have been a larger team working behind the scenes - particularly given that the lawyers had to sift through 20 boxes of discovered documents. ${ }^{70}$ Further questions arise in relation to the massive undertaking as to damages that the plaintiffs had to give when they sought the interim injunction - how was this money raised, and what happened to it after the decision was issued? A closer examination of the pro bono aspects of the case is also warranted to the extent that it sheds light on the pro bono ethos and the role of lawyers in public interest litigation, particularly as it pertains to the common law doctrine of maintenance. The two sections that follow examine these two issues in turn - the problem of maintenance first, and the pro bono elements of the litigation second.

\section{IV "BUSYBODIES, CRANKS AND MISCHIEF-MAKERS": THE PROBLEM OF MAINTENANCE}

This part of the article examines the common law doctrine of maintenance. It first traces the doctrine back to its origins in medieval England. It then examines the applicability of the doctrine in New Zealand, before making some tentative conclusions about how the lawyers involved in the Finnigan $v$ NZRFU litigation were able to avoid it.

\section{A The Origins of the Doctrine of Maintenance in England}

The doctrine of maintenance originated in late medieval England. ${ }^{71}$ The common law sought to counter the illegitimate actions of what Lord Mustill would later characterise as "unscrupulous men of power". ${ }^{72}$ In the context of the feudal system, nobles frequently sought to oppress the poor and vulnerable through the "systematic promotion of lawsuits". ${ }^{73}$ To deal with this phenomenon, the English common law developed three offences. The first was barratry - the offence of frequently

70 Thomas and others, above n 64 .

71 For general reading, refer to Percy Winfield "History of Maintenance and Champerty" (1919) 35 LQR 50; Percy Winfield The History of Conspiracy and Abuse of Legal Procedure (Cambridge University Press, Cambridge, 1921); Percy Winfield The Present Law of Abuse of Legal Procedure (Cambridge University Press, Cambridge, 1921); and William Tapp An Inquiry Into the Present State of the Law of Maintenance and Champerty (V \& R Stevens, London, 1861).

72 Giles v Thompson [1994] AC 142 at 153 (HL).

73 Law Commission Subsidising Litigation (NZLC R72, 2001) at 1. 
stirring up suits. ${ }^{74}$ The second was maintenance - the maintaining, supporting, or promoting of the litigation of another. The third was champerty - the "particularly obnoxious" sibling of maintenance where a lawyer supports a claimant in exchange for a share in the fruits of the claim.

Maintenance existed as a crime and a tort as early as the 17th century, when it was described as "a taking in hand, a bearing up or upholding of quarrels or sides, to the disturbance of the common right". ${ }^{75}$ English courts defined the doctrine further over the years. One case to note at this stage is Bradlaugh $v$ Newdegate. ${ }^{76}$ There, Lord Coleridge CJ thought there was a distinction, albeit a slight one, between instigation of a suit and support of a suit already commenced. ${ }^{77}$ While that statement was strictly speaking obiter, it suggests that the actions of the lawyers in the Finnigan $v$ NZRFU litigation verged on a particularly egregious type of maintenance - the instigation of a suit.

Lord Coleridge $\mathrm{CJ}$ also accepted that maintenance "must be something against good policy and justice ... something that in a legal sense is immoral" ${ }^{78}$ English case law makes it clear that the doctrine against maintenance is guided by public policy concerns. At the turn of the 20th century, the English Court of Appeal in British Cash \& Parcels Conveyors Ltd v Lamson Store Service Co Ltd explained how maintenance "is directed against wanton and officious intermeddling with the disputes of others in which the [maintainer] has no interest whatever, and where the assistance he renders to the one or the other party is without justification or excuse ${ }^{\prime 79}$ If there is a justification for the lawyer intermeddling, then it will not be maintenance.

The English courts established a number of justifications that could operate as quasi-defences to allegations of maintenance. These are open ended.

The most interesting established justification is that of charity. The first authority to this effect is Rothewell v Pewer, from as far back as the 15th century. There, Martin J of the Common Pleas, stated "I can give gold or silver to a man that is poor to maintain his plea if he himself cannot through his poverty: this is not maintenance against the law". ${ }^{80}$

74 "Advertising, Solicitation and the Profession's Duty to Make Legal Counsel Available" (1972) 81 Yale LJ 1181.

75 Bradlaugh $v$ Newdegate (1883) 11 QBD 1 at 5.

76 Bradlaugh v Newdegate, above n 75.

77 At 8 .

78 At 10 .

79 British Cash \& Parcels Conveyors Ltd v Lamson Store Service Co Ltd [1908] 1 KB 1006 at 104 (emphasis added).

80 Rothewell v Pewer (1431) YB 9 Hen VI. 
There is semantic debate over whether pro bono should in fact be a characterised as a "charitable purpose". As Deborah Rhode writes, "pro bono work is not simply a philanthropic exercise; it is also a professional responsibility". ${ }^{81}$ The legal definition of charity found in the Charitable Uses Act 1601 (commonly referred to as the Statute of Elizabeth I) supports the idea that acting pro bono is not necessarily a "charitable purpose". ${ }^{82}$ The preamble lists purposes that are charitable in the eyes of the law:

The relief of aged, impotent, and poor people; the maintenance of sick and maimed soldiers and mariners;

schools of learning; free schools and scholars in universities; the repair of bridges, ports, havens,

causeways, churches, sea banks, and highways; the education and preferment of orphans; the relief, stock,

or maintenance of houses of correction; marriages of poor maids; support, aid, and help of young

tradesmen, handicraftsmen and persons decayed; the relief or redemption or prisoners or captives; and the

aid or ease of any poor inhabitants covering payments of fifteens, setting out of soldiers, and other taxes.

A similar definition is found in New Zealand in s 5 of the Charities Act 2005, which gives "the relief of poverty" and "the advancement of education or religion" as examples of charitable purposes. Acting pro bono is therefore unlikely to be classified as a charitable purpose.

If acting pro bono does not fall under the "charitable purposes" exemption, it is nonetheless likely to be a justification for maintenance, albeit one yet to be recognised by the courts. ${ }^{83}$ English courts were quick to recognise new justifications for maintenance. ${ }^{84}$

Maintenance and champerty remained torts and crimes in England until the Criminal Law Act 1967. Analysing the old law of maintenance in England has nevertheless proven useful for two reasons. First, New Zealand inherited its law from England and, as will be seen in the following section, maintenance remains part of the law in New Zealand. Secondly, in unearthing the old law on justifications for maintenance, it might be possible to exonerate the lawyers in the Finnigan $v$ NZRFU litigation of any wrongdoing.

81 Deborah Rhode "Cultures of Commitment: Pro Bono for Lawyers and Law Students" (1999) 67 Fordham LR 2415 at 2421.

82 Charitable Uses Act 1601 (Eng) 43 Eliz I c 4, preamble.

83 Taggart, above n 14, at 93.

84 "Without entering into a detailed analysis of the cases, it may be said that the trend of judicial decision has been to increase the number of interests which the courts are prepared to accept as lawful justification". Law Commission for England and Wales Proposals for Reform of the Law Relating to Maintenance and Champerty (Law Com No 7, 1996) at 10. 


\section{B Maintenance in New Zealand}

The doctrine of maintenance became part of New Zealand law with the English Laws Act $1858 .{ }^{85}$ That statute retrospectively made English law applicable from 14 January 1840. Maintenance therefore continues to exist as a tort in New Zealand, despite the lack of any statutory provision to that effect. Maintenance no longer exists as a crime however, as it was not consolidated by statute in 1893.86

The Laws of New Zealand adopts British Cash \& Parcel Conveyors Ltd v Lamson Store Service Co Ltd in defining maintenance as where "a person, without lawful justification, interferes with the disputes of others by assisting a party to a dispute to bring or defend an action". ${ }^{87}$ Interestingly, the Laws of New Zealand notes how "it has been held that it is no defence to an action for maintenance that the defendant supported the litigation out of a sense of public duty". ${ }^{88}$ The lawyers in the Finnigan $v$ NZRFU litigation would therefore have to find another justification. As per the old law in England, "it is a good defence to an action for maintenance" in New Zealand "that the defendant supported another's litigation out of charitable motives". ${ }^{89}$

It was noted above that acting pro bono is unlikely to fall within the strict confines of the legal definition of "charitable purposes". The 1934 case Sievright $v$ Ward shows that the New Zealand courts may nevertheless recognise an exemption for acting pro bono publico. ${ }^{90}$ In that case, Ostler $\mathrm{J}$ held that a lawyer will not be guilty of maintenance if they "take up [an] action" that is "consistent with the honour of the profession". ${ }^{91}$ It is therefore likely, as in England, that a lawyer acting pro bono will not be guilty of maintenance. ${ }^{92}$ This cannot be confirmed however, as there are no cases directly addressing the matter.

There are a number of New Zealand cases where maintenance might have been argued before the courts, but was ultimately not pursued. One such case is Fitzgerald v Muldoon. ${ }^{93}$ The first theory that

85 See David V Williams "The Pre-History of the English Laws Act 1858: McLiver v Macky (1856)" (2010) 21 VUWLR 361.

86 See also Crimes Act 1961, s 9: "No one shall be convicted of any offence at common law".

87 Laws of New Zealand Tort: Abuse of Legal Procedure: Maintenance and Champerty (online ed) at [180] (emphasis added).

88 At [183].

89 At [180].

90 Sievright $v$ Ward [1935] NZLR 43 (SC).

91 At 48.

92 Laws of New Zealand, above n 87, at [180].

93 Fitzgerald v Muldoon [1976] 2 NZLR 615 (SC). 
arose in relation to Fitzgerald $v$ Muldoon was that the case was "initiated (and paid for) by either the union movement or the New Zealand Labour Party". ${ }^{94}$ This is incorrect. ${ }^{95}$ Another theory that gained traction was that Dr Barton put Fitzgerald up to the case. This is given some credence by Muldoon's statements after the case. In a newspaper interview in June 1976, Muldoon suggested counsel had "I rather suspect ... a good deal to do with the original decision to take the case". 96 This suggestion "of initiation and subsidisation" was strongly denied by Dr Barton. ${ }^{97}$ In the subsequent hearing about costs in September 1976, Dr Barton went so far as to publically disclose the origins of the case. ${ }^{98} \mathrm{Dr}$ Barton was on holiday over Christmas 1975 when "a message was left for [him] by 'a qualified lawyer in the Government service', who was interested in taking, personally, a case". ${ }^{99}$ For personal reasons, the then-intending plaintiff was unable to take the case. At that point, Dr Barton "was approached by Paul Fitzgerald", who was "willing to take over the legal challenge". ${ }^{100}$ Dr Barton also noted that he had not subsidised the case - the legal fees he charged in fact amounted to half of Fitzgerald's salary. ${ }^{101}$ Muldoon would later accept that Dr Barton had not initiated the case (that is, committed maintenance) or subsidised it. ${ }^{102}$ It was later said that Dr Barton was in fact the only lawyer Muldoon ever respected. ${ }^{103}$

The lack of case law raises the question of whether maintenance can reasonably be regarded as part of New Zealand law. Todd thought that "little would be lost by abolishing maintenance" as a tort in New Zealand. ${ }^{104}$ There have "been no reported New Zealand cases in which a claim in tort has succeeded". ${ }^{105}$ However, in 2001, the Law Commission released a report suggesting that maintenance (and the associated doctrine of champerty) remained part of New Zealand law. ${ }^{106}$ Nothing has

94 Stephen Kós "Constitutional Collision: Fitzgerald v Muldoon v Wild" (2014) 13 Otago LR 243 at 274.

95 At 274 .

96 At 274.

97 At 274

98 Fitzgerald v Muldoon HC Wellington A118/76, 13 September 1976.

99 Kós, above n 94, at 276 (footnotes omitted).

100 At 276 .

101 At 292

102 (4 November 1976) 407 NZPD 3678-3679.

103 Kós, above n 94, at 293.

104 Stephen Todd The Law of Torts in New Zealand (7th ed, Thomson Reuters, Wellington, 2016) at 1065.

105 Law Commission, above n 71, at 6.

106 At 5 . 
changed since then that might warrant a reconsideration of this - although the emerging issue of litigation funding is likely to change that. ${ }^{107}$

\section{How Did the Plaintiffs' Lawyers Avoid the Doctrine?}

Having established that maintenance remains part of New Zealand law, the next question to answer is how the lawyers managed to avoid the doctrine.

A somewhat blunt response to this would be that no proceedings in maintenance were taken against the lawyers after the case. This was in spite of Douglas White noting during the litigation that the lawyers had approached the plaintiffs. One might speculate that the lawyers involved may have been regarded as "men of power", but not "unscrupulous men of power". ${ }^{108}$ That is, the lawyers acting for the plaintiffs (three of whom would later become judges) were regarded as respected members of the legal profession and the defendants were cautious not to accuse them of "wanton and officious intermeddling". ${ }^{109}$ This is reflected in the Lawyers and Conveyancers Act (Lawyers: Conduct and Client Care) Rules 2008. Rule 13.8 provides that a lawyer engaged in litigation ought to be cautious when attacking the character or reputation of opposing counsel.

A more conservative view, and one that is undoubtedly favourable to the lawyers involved in the case, is that their actions simply did not amount to maintenance. One can rely here on the exemption to maintenance where a lawyer acts for charitable purposes. As noted above, there is a tenuous line of English authority that a person is not committing maintenance if acting for charitable purposes. This may encompass lawyers acting pro bono. While the charitable motives exemption is included in the Laws of New Zealand, there is no case authority to that effect in New Zealand. The New Zealand Law Commission has explicitly warned against the utility of English cases in the wake of the abolition of the doctrine of maintenance in that jurisdiction. ${ }^{110}$ Yet an exemption for lawyers acting pro bono makes conceptual sense. Maintenance developed alongside champerty, and the two are in many respects inextricably linked. If one encourages litigation with a view to sharing in the proceeds of the claim, then one has committed both maintenance and champerty. The logical corollary of this, combined with the fact that modern cases of maintenance nearly always involve a lawyer arranging to get a fee, ${ }^{111}$ is that, if acting pro bono, then the lawyer has not committed maintenance. Such an understanding would also serve to encourage lawyers to take cases pro bono. Surely this is to be

107 The New Zealand Law Commission notes how the "principal modern significance of the old rules is in the context of contingency fees and of the rule prohibiting the assignment of a bare cause of action". Law Commission, above $\mathrm{n} 73$, at 2 .

108 Giles v Thompson [1994] 1 AC 142 (HL) at 153 (emphasis added).

109 British Cash \& Parcels Conveyors Ltd v Lamson Store Service Co Ltd, above n 79.

110 Law Commission, above n 73, at 6.

111 At 2 . 
encouraged, given that acting pro bono is a key aspect of a lawyer's broader duty to the community. ${ }^{112}$ It can hardly be said that acting pro bono publico was what Lord Coleridge had it mind when he explained how "the maintainer must have been actuated by a bad motive". ${ }^{113}$

\section{Conclusion to Part IV}

This part of the article has raised more questions than it has answered. Of ongoing concern is whether maintenance should be "abolished, codified, or left untouched". ${ }^{114}$ The section has, it is hoped, served to clear the lawyers involved in the case of any wrongdoing. In the weeks after the judgment, the lawyers received more than their fair share of criticism. This is no more evident than in the Parliamentary Debates. There, the Hon APD Friedlander criticised Ted Thomas: ${ }^{115}$

I said that the matter was a jack-up, because in evidence that went before the court it was clear that $\mathrm{Mr}$

Thomas and one other counsel approached the alleged members of rugby clubs and got them to take case.

Ted Thomas' actions were also criticised by the Hon John Banks. ${ }^{116}$ This section has shown that such criticism is a historical misnomer. While Douglas White alluded to the possibility of maintenance in court, no proceedings were ever taken against the lawyers involved in the case ex post facto. In any event, the lawyers would most likely have had an established justification for their actions - acting pro bono publico. In the event that maintenance is not an established justification, there is nonetheless room to argue that it ought to be recognised as such by the courts.

\section{THE PRO BONO EFFORTS IN 1985}

There are two aspects of the pro bono efforts in 1985 that call for further discussion. The first of these is the nature of the pro bono team. The case reports only record Ted Thomas as senior counsel, and Rodney Hansen as instructing solicitor. This does not do justice to the other lawyers involved in the case. The second question relates to the whereabouts of the money collected to cover the undertaking that was required for an interim injunction application.

\section{A The Pro Bono Team}

The court team comprised Ted Thomas (senior counsel), John Marshall (whom Ted Thomas found on one of the committees that had been established in 1985), Sian Elias, and Ted Thomas' son

112 Duncan Webb, Kathyrn Dalziel and Kerry Cook Ethics, Professional Responsibility and the Lawyer (3rd ed, LexisNexis, Wellington, 2016) at 356.

113 Bradlaugh v Newdegate, above n 75, at 9.

114 Law Commission, above n 73, at 7.

115 (1985) 464 NZPD 5659.

116 (1985) 464 NZPD 5658. 
(the dogsbody). ${ }^{117}$ The team was joined in conferences by Rodney Hansen (who thought of the idea of challenging the New Zealand Rugby Football Union on the basis of its Constitution). The presence of John Marshall is interesting in so far as it can be seen as a sign of changing times. John Marshall's father and namesake had been the leader of the National Party in the 1970s - an era where politicians almost exclusively called for politics and rugby to be kept apart. It appears that John Marshall Snr fondly known as "Gentleman Jack" - was no exception. In 1973, as Leader of the Opposition, Gentleman Jack had criticised the Government for refusing to allow the "all-white" Springbok team to tour. ${ }^{118}$ Gentleman Jack's sentiment to the 1985 tour remains unclear, but John Marshall, who had earlier in his career set up the first two free legal advice centres in Wellington, fondly recalled taking the case pro bono - "the work you do on a pro bono basis is the most satisfying". 119

\section{$B$ Funding the Interim Injunction Application}

Part II discussed the emergence of panels in 1981, where lawyers made themselves available to help protestors pro bono publico. A similar phenomenon occurred in 1985, albeit in a slightly different form. Ted Thomas recalls the establishment of committees around New Zealand. ${ }^{120}$ The purpose of these committees was not to provide legal representation pro bono publico, as it had been in 1981 . Rather, the committees were established with the simple aim of raising enough money to cover the undertaking as to damages that the plaintiffs had to make as part of the injunction application. After the successful interim injunction, these funds were unnecessary. In a turn of events that speaks largely to the character of those involved, these funds were not returned to the lawyers who had donated the money. Rather, Ted Thomas recalls transferring the funds to a bank in South Africa for Arnold Stofile. The funds were used to appeal Arnold Stofile's imprisonment upon his return to South Africa. Stofile had been called as the plaintiffs' opening witness - an event that is widely credited with turning the scale in their favour. ${ }^{121}$

117 Taggart, above n 3, at 185 .

118 Jon Gemmell The Politics of South African Cricket (Routeledge, London, 2004) at 132.

119 Geoff Adlam "John Marshall QC CNZM, 1946-2015" (14 June 2015) New Zealand Law Society <www.lawsociety.org.nz>

120 Thomas, above n 55 .

121 Thomas and others, above n 64. See also Lauren Peacock "National Ideals or National Interest: New Zealand and South Africa, 1981-1994" (MA Thesis, Victoria University, 2013) at 80: "Emotive testimony from the Reverend Makhenkesi 'Arnold' Stofile, who had travelled illegally to New Zealand from South Africa via Zimbabwe, on the possible effects that such a tour would have, probably contributed to the outcome." 


\section{RE-EVALUATING THE SIGNIFICANCE OF THE CASE}

This part of the article focuses on whether Justice Glazebrook's statement - that the Finnigan $v$ $N Z R F U$ litigation is more noteworthy for its social significance than its legal significance - still stands, in light of the two previous sections. ${ }^{122}$

\section{A Legal Significance}

Justice Glazebrook essentially argues that the Finnigan $v$ NZRFU litigation did not establish "lasting legal precedent". ${ }^{123}$ This is true on a number of levels. For a start, the "court's ruling was of a limited nature". ${ }^{124}$ Justice Glazebrook places particular emphasis on the interim injunction granted by Casey J, noting it "has no precedent value". ${ }^{125}$ This view was shared by Professor Taggart, who stated that "Finnigan (No 1) has had little impact in subsequent standing cases", largely because "standing as a threshold issue is almost a dead letter" in New Zealand. ${ }^{126}$

To leave an analysis of the legal significance of the case there is a mistake. Professor Taggart, for one, noted that there is still some legal significance to Finnigan $v$ NZFRU in so far as it considerably blurred "the line between private law and public law" and was a precursor to subsequent judicial review of "self-regulatory, corporatized and other bodies at arm's length from the government". ${ }^{127}$

While the legal significance of the Finnigan $v$ NZRFU litigation has been questioned in New Zealand, it is internationally recognised as a leading sports law case. Simon Gardiner notes the "decision ... went some way to allaying fears that a gap may exist where a potential claimant could be denied redress through the courts by ... a narrow construction of the nature of sports governing bodies in private law proceedings". ${ }^{128}$ Jack Anderson is more emphatic, stating that Finnigan (No 1) "deserves its place as one of the most significant cases in international sports law". ${ }^{129}$

This article has shown that the Finnigan $v$ NZRFU litigation is also legally significant in relation to the tort of maintenance. The Finnigan $v$ NZRFU litigation shows that lawyers acting pro bono are

122 Glazebrook, above n 2, at 347.

123 At 348 .

124 At 349.

125 At 350 .

126 Taggart, above n 3, at 190.

127 At 191.

128 Simon Gardiner and others Sports Law (3rd ed, Cavendish, London, 2006).

129 Jack Anderson Leading Cases in Sports Law (Asser Press, New York, 2013) at 121. For a discussion of the impact of Finnigan (No 1) in New Zealand sports law, see: Rowan Armstrong "The Whistle has Blown ... Game Over ... Or is it Really? Challenging the Decisions of Sports Governing Bodies in New Zealand" [2008] Canta LR 65. 
unlikely to be held liable for maintenance, even if they draft a lawsuit before actively hunting out an appropriate plaintiff to take the case.

One can also infer a relatively liberal judicial approach to the issue of busybodies. The Rt Hon Sir Ivor Richardson cited the Finnigan (No 1) decisions as authority that "[t]he New Zealand courts have ... never felt oppressed by a busybody problem." 130 This can be compared to the position in England. There, the apartheid regime gave rise to a number of cases where plaintiffs, and sometimes their lawyers, were characterised as "busybodies". One such case is Gouriet v Union of Post Office Workers. ${ }^{131}$ It was put before the Court that a change to the present law surrounding injunctions "would open what were called the 'floodgates to a multiplicity of claims by busybodies"'. ${ }^{132}$ The language of "busybodies" in Gouriet was inherited from Inland Revenue Commissioners v National Federation of Self-Employed and Small Businesses Ltd, where Lord Scarman noted how the requirement as to standing "prevent[s] abuse by busybodies, cranks, and other mischief-makers". ${ }^{133}$

\section{B Social Significance}

The social significance of the Finnigan $v$ NZRFU litigation is indisputable. The decision had effects far beyond simply stopping the tour of South Africa. Justice Glazebrook notes how the decision helped "facilitate a broader understanding of race relations in New Zealand". ${ }^{134}$ Of particular importance in this respect was Stofile's testimony. John Carlin notes how Stofile's testimony "was responsible for public support for sanctions against South Africa jumping from $40 \%$ to $75 \%$ in New Zealand". 135

This article has shown that the social significance of the Finnigan $v$ NZRFU litigation extends further, into the role of lawyers in the community. ${ }^{136}$ There has been increasing concern about the state of public interest litigation in New Zealand. Rick Bigwood first discussed the topic at length in 2006. ${ }^{137}$ Sam Bookman, writing in 2013, argued that public interest litigation should be embraced in

130 Ivor Richardson "The Harkness Henry Lecture: Public Interest Litigation" (1995) 3 Wai L Rev at 12 (emphasis added).

131 Gouriet v Union of Post Office Workers [1978] AC 435 (HL).

132 At 510 .

133 Inland Revenue Commissioners v National Federation of Self-Employed and Small Businesses Ltd [1982] AC 617 (HL) at 653.

134 Glazebrook, above n 2, at 352.

135 John Carlan Invictus: Nelson Mandela and the Game That Made a Nation (Atlantic Books, London, 2008) at 67.

136 Watt, above n 13, has analysed how the case challenges the traditional separation of the legislature and the judiciary.

137 Rick Bigwood Public Interest Litigation (LexisNexis, Wellington, 2006). 
New Zealand. ${ }^{138}$ The subject remains a vexed one, as illustrated by the limited litigation-funding scheme in New Zealand. The Finnigan $v$ NZRFU litigation serves as a reminder of the merits of public interest litigation. Anti-apartheid litigation shows that, if the cause is good, lawyers will rise to it: "there was a significant amount of elite support both in the legal profession and in society for the cause". ${ }^{139}$

Revisiting the litigation also serves as a reminder of the importance of the pro bono ethos. The obligation to act pro bono publico remains a key tenet of a lawyer's ethical duty to the community. As Duncan Webb notes, "a lawyer is expected to contribute to the availability of legal advice to those unable to pay". ${ }^{140}$ Without a strong pro bono ethos, the Finnigan $v$ NZRFU litigation would never have come before the courts - and neither would Parsons v Burk or Ashby v Minister of Immigration. The pro bono ethos of today's legal community has come under increasing scrutiny. Deborah Rhode writes that "nowhere is the gap between professional ideals and professional practice more apparent than on issues of pro bono responsibility". ${ }^{141}$ In the United States, lawyers are expected to render at least fifty hours of pro bono publico legal services a year, yet "the average for the profession ... is less than half an hour per week". ${ }^{142}$ These concerns have been echoed in New Zealand, where there have been calls for mandatory pro bono requirements. Rhode notes that such proposals "have come and gone, but mainly gone". ${ }^{143}$ The Finnigan $v$ NZRFU litigation suggests there may nonetheless be some merit to the idea. Another avenue for exploration is the incorporation of pro bono initiatives in law schools. By enlisting students "early in their legal careers, these initiatives attempt to inspire an enduring commitment to public service". ${ }^{44}$ There has been some traction for this in New Zealand; Canterbury law school announced a compulsory pro bono programme for law students in 2013, although the current status of that initiative is unclear. ${ }^{145}$ Other universities have introduced schemes

138 Sam Bookman "Providing Oxygen for the Flames? The State of Public Interest Litigation in New Zealand" (2013) 25 NZULR 442.

139 Taggart, above n 14 , at 91 .

140 Duncan Webb, Kathyrn Dalziel, and Kerry Cook Ethics, Professional Responsibility and the Lawyer (3rd ed, LexisNexis, Wellington, 2016) at 356.

141 Rhode, above n 81, at 2415.

142 At 2415.

143 At 2416.

144 At 2416.

145 Canterbury Law School has recently introduced mandatory pro bono work for students. Kurt Bayer "Law students to be rewarded for pro bono work" The New Zealand Herald (online ed, Christchurch, 19 September 2013). 
where law students receive credit for time spent volunteering in community law centres. ${ }^{146}$ This is to be welcomed.

\section{CONCLUSION}

This article has examined the Finnigan $v$ NZRFU litigation from a different perspective. Existing literature primarily focuses on the administrative law significance of the anti-apartheid litigation (in the case of Taggart), the status of Finnigan $v$ NZRFU as a leading case (in the case of Glazebrook), or whether what was in essence a political dispute was appropriate for the courtroom (in the case of Watt). The focus of this article has been on two elements of the litigation that existing literature does not examine - the problem of maintenance, and the pro bono elements of the anti-apartheid litigation in New Zealand.

It first discussed how the actions of the lawyers related to the common law doctrine of maintenance. Contemporary criticism of the lawyers focused on how they approached the plaintiffs with the case, rather than the other way around. As per Bradlaugh $v$ Newdegate, this prima facie looks like maintenance - the initiation of a legal suit. Examining the old law in England revealed a number of justifications for maintenance. One justification to emerge was that of "charitable purposes". If acting pro bono publico does not fall under that ground, there are nonetheless strong public policy reasons for it being recognised as a ground in and of itself. A close examination of the doctrine of maintenance has therefore served to clear the lawyers involved of any wrongdoing.

Having exonerated the lawyers of any wrongdoing, the article then closely examined the pro bono ethos. Analysis of litigation prior to 1985 revealed a strong trend of lawyers making themselves on a pro bono basis in the fight against apartheid. Anti-apartheid litigation in 1973 and 1981 both featured counsel who appeared pro bono publico. The Finnigan $v$ NZRFU litigation can be seen as a culmination of the pro bono litigation that came before it.

The legal and social significance of the case ought to be expanded to take into account the applicability of the doctrine of maintenance and the pro bono ethos respectively. Both of these elements are important today - maintenance remains part of New Zealand law, and pro bono remains a crucial tenet of a lawyer's ethical obligation to the community. Cause lawyers can take solace from the Finnigan $v$ NZRFU litigation. It shows that the instigation of litigation is unlikely to amount to maintenance in New Zealand, provided the lawyer acts pro bono publico. It also shows the power of the lawyer in affecting social change. Legal practitioners and law students alike would do well to remember what Elias CJ stated about Dr Barton on his passing: "He reminded all of us why we had wanted to be lawyers and of what can be achieved through law". 147

146 Piers Davies "Community Law Centres" in Ian Barker (ed) Law Stories: Essays on the New Zealand Profession 1969-2003 (LexisNexis, Wellington, 2003) 153 at 173. Such practice remains common today.

147 Sian Elias "The Life in Law of George Paterson Barton QC" (2012) 43 VUWLR 3 at 4. See also "Appointment of Queen's Counsel: Dr George Barton" [1990] NZLJ 14 for similar comments on his elevation to silk in 
1990: "although at the top of his profession, Dr Barton is prepared to match his fees to the ability of individuals to pay". 